Jurnal IImiah AL-Jauhari (JIAJ)

Volume 4 No 1, (Juni 2019): 219-238

p-ISSN: $2541-3430$

e-ISSN: $2541-3449$

Website: http://journal.iaingorontalo.ac.id/index.php/aj

\title{
Layanan Nikah Tidak Tercatat di Gorontalo: Explorasi dan Rekonstruksi
}

\author{
Ahmad Faisal, Mahmud Bakari \\ (Institut Agama Islam Negeri (IAIN) Sultan Amai Gorontalo, \\ Universitas Muhammadiyah Gorontalo) \\ ahmadfaisal@iaingorontalo.ac.id, mahmudbakari@gmail.com
}

\begin{abstract}
This article aims to explore unmarried marriage services in Gorontalo. The study uses qualitative methods with a descriptive approach. The results of the study show that: (1) the widespread practice of marriage is not recorded in Gorontalo due to the availability of unregistered marriage services that are easy to access and not clandestine; (2) as for services not recorded easily and extensively in the background of several factors, namely; economics, culture, law, education, social, etc., this phenomenon leaves one problem that must be solved, namely the need to reconstruct a non-simplistic understanding of marriage. (3) Marriage must be returned to the essence of Islamic law. An epistemological problem that leaves a simplistic view of marriage must be reconstructed, so that there is no longer a view that Islamic marriage is merely a contract to legalize husband and wife relations that are more biologically nuanced. Support and awareness of all elements of the community are needed to further realize the sacred values of maqashid al-sharia.
\end{abstract}

\begin{abstract}
Abstrak
Artikel ini bertujuan mengeksplorasi layanan nikah tidak tercatat di Gorontalo. Kajian menggunakan metode kualitatif dengan pendekatan deskriptif. Hasil penelitian menunjukkan bahwa: (1) maraknya praktik nikah tidak tercatat di Gorontalo disebabkan karena tersedianya
\end{abstract}


layanan nikah tidak tercatat yang mudah akses dan tidak sembunyisembunyi; (2) adapun layanan tidak tercatat mudah dan meluas dilatar belakangi beberapa faktor, yaitu; ekonomi, budaya, hukum, pendidikan, sosial, dan lain-lain, fenomena tersebut menyisakan satu problem yang harus diselesaikan yakni perlunya rekonstruksi pemahaman yang tidak simplistik tentang perkawinan. (3) Perkawinan harus dikembalikan pada esensi syariat Islam. Problem epistemologis yang menyisakan pandangan simplistik tentang perkawinan harus direkonstruksi, sehingga tidak lagi berkembang pandangan bahwa perkawinan Islam hanya sekedar akad untuk melegalkan hubungan suami istri yang lebih kental nuansa biologisnya. Diperlukan dukungan dan kesadaran semua elemen umat untuk lebih mewujudkan nilai-nilai suci dari maqashid al-syariah.

Kata kunci: layanan nikah; nikah tidak tercatat; rekonstruksi;

\section{Pendahuluan}

Para ulama sepakat bahwa tujuan disyariatkannya Islam adalah untuk mendatangkan kemaslahatan dan menolak kemudharatan. ${ }^{1}$ Salah satu nuktah penting dari syariat Allah untuk mencapai kemaslahatan tersebut adalah syariat perkawinan. Untuk memastikan syariat tersebut mencapai maqashid yang ditargetkan, maka dibuatlah sejumlah persyaratan baik yang bersifat substantif maupun bersifat adiministratif. Secara substantif, syarat-syarat dan rukun perkawinan telah diuraikan secara rinci dalam kajian-kajian fikih, sedangkan secara administratif, ketentuannya telah dirumuskan dalam peraturan perundang-undangan. Dengan demikian, dapat ditegaskan lebih awal bahwa persoalan perkawinan, bukan hanya persoalan agama tetap juga persoalan negara.

Salah satu rukun nikah menurut Abu Hanifah, Syafi'i dan Malik adalah syahadah atau kesaksian. Rukun ini kemudian diimplementasikan dalam Undang-Undang RI Nomor 1 Tahun 1974 tentang Perkawinan. Pada pasal 2 ayat 2 disebutkan bahwa "tiap-tiap perkawinan dicatat menurut peraturan perundangan yang berlaku". Peraturan lain yang berlaku di Indonesia juga menetapkan bahwa pelaksanaan pencatatan dilakukan melalui pegawai pencatat perkawinan.

Berdasarkan ketentuan tersebut di atas, perkawinan hanya diakui sah jika tercatat di lembaga yang diatur oleh undang-undang untuk kepentingan tersebut. Tetapi dalam realitasnya, muncul

\footnotetext{
${ }^{1} \mathrm{Abu}$ Ishaq al-Syatibiy, al-Muwafaqat fiy Ushul al-Syari'ah, Jilid III (Beirut: Dar al-Ma'rifah li al-Thiba'ah wa al_Nasyr, 1975), h. 6.
} 
berbagai varian pernikahan di luar ketentuan seperti yang disebut dan diisyaratkan dalam Undang-Undang RI No. 1 Tahun 1974 tersebut. Maraknya pernikahan tidak tercatat di kalangan masyarakat, merupakan bukti terjadinya varian perkawinan yang semangatnya berbeda jauh dari apa yang diatur oleh Undang-Undang No. 1 Tahun 1974 pasal 2 ayat 2 tersebut.

Fenomena nikah tidak tercatat disinyalir terjadi di semua tempat dalam berbagai skala, baik secara terang-terangan maupun secara sembunyi-sembunyi. Praktik secara terang-terangan, salah satunya dapat ditemukan Di Gorontalo. Adalah Syukri Alinti yang menyediakan layanan nikah tidak tercatat dan bertindak sebagai juru nikah "swasta". Sebelumnya, bahkan sejak tahun 1976 Nur Alinti (bapak kandung Syukri Alinti), telah menyediakan layanan jasa yang sejenis. Sampai tahun 2017 saja, Nur Alinti mengaku telah menikahkan tidak kurang dari 50 ribu pasangan dengan berbagai latar belakang sosial. Angka tersebut sejatinya akan terus bertambah sekiranya maut tidak keburu menjemput. Sepeninggal Nur Alinti, maka layanan tersebut diteruskan oleh anaknya Syukri Alinti. Ibarat fenomena gunung es, sosok Syukri Alinti hanyalah satu dari sekian banyak contoh adanya juru nikah swasta yang bertebaran di manamana. ${ }^{2}$ Barangkali bedanya hanyalah karena Syukri Alinti berani terang-terangan, sementara yang lain berpraktek secara sembunyisembunyi.

Secara teoritis, sebuah layanan jasa dapat terus eksis jika mendapat dukungan dari para pelanggan. Dengan demikian, secara sederhana dapat diasumsikan bahwa praktik tersebut berkorelasi postif dengan maraknya permintaan layanan dari para calon pengantin. Atas dasar itulah, maka artikel ini berusaha mengeksplorasi penyebab maraknya praktik nikah tidak tercatat tersebut. Tidak sekedar melakukan eksplorasi, kajian ini juga bermaksud melakukan kritik dan rekonstruksi sehingga persoalannya dapat dipetakan secara lebih konfrehensif.

Penelitian ini merupakan penelitian lapangan (field research), dengan beberapa model pengumpulan data, meliputi observasi (pengamatan), wawancara mendalam (deept interview), dan metode dokumentasi. Penentuan populasi dan sampel responden dilakukan dengan teknik snow-ball, yaitu penggalian data melalui wawancara mendalam dari satu responden ke responden lainnya dan seterusnya sampai data sudah jenuh dan peneliti tidak lagi menemukan informasi

\footnotetext{
${ }^{2}$ Berdasarkan temuan penelitian, di daerah Siendeng saja terdapat setidaknya 8 penyedia layanan nikah tidak tercatat selain Syukri Nur Alinti. Mereka adalah Kisman Bukoting, Akuba Yusuf, Ismail Syukur, Hasyim Usman, Yunus Olii, Muh. Amin, Muh. Akaji dan Takrim Rahim.
} 
baru. Sementara teknik analisis isi (content analyisis) digunakan untuk menggambarkan kategori-kategori yang ditemukan sehingga dapat melahirkan analisis yang obyektif tentang terjadinya simplikasisasi dalam layanan dan praktik nikah tidak tercatat di Gorontalo

\section{Potret Perkawinan Layanan Nikah Tidak Tercatat}

Daerah Siendeng di Gorontalo sesungguhnya hanyalah wilayah setingkat kelurahan/desa yang sejatinya tidak begitu popular secara administratif. Tetapi di Gorontalo, Kelurahan Siendeng menjadi sangat populer justru bukan karena prestasi atau kelebihankelebihan lainnya. Ia menjadi populer karena di tempat inilah tersedia layanan jasa nikah tdak tercatat yang secara umum diketahui oleh masyarakat Muslim di Gorontalo.

Meskipun tidak lagi seheboh ketika Nur Alinti masih hidup, tetap saja msyarakat Muslim mengidentikkan Siendeng dengan Layanan Jasa Nikah tidak tercatat yang pernah dirintis Nur Alinti. Fenomena ini menjadi semakin menarik mengingat Muhammad Nur Alinti adalah mantan pegawai Kementerian Agama (dulu masih bernama Departemen Agama) yang mengundurkan diri pada tahun 1967 dan mulai berpraktek sebagai "juru nikah swasta".

Secara panjang lebar, Syukri Nur Alinti menceritakan pandangan dasar yang dianut Bapaknya. Menurut Syukri, Nur Alinti berpandangan bahwa pencatatan pernikahan seharusnya dilakukan setelah akad nikah dilakukan. Bahkan idealnya setelah paling kurang 6 (enam) bulan berselang setelah akad nikah dilakukan, setelah dipastikan tidak ada problem dan gugatan barulah didaftarkan dan diterbitkan buku akta nikah. Meskipun kedengarannya apologis, Syukri juga mengaku memberikan layanan nikah tidak tercatat terhadap yang menginginkannya, karena pertimbangan maslahat yang lebih luas. Ia mengandaikan sekiranya pemohon dibiarkan tidak menikah, sementara lembaga pernikahan formal tidak dapat melayani dengan alasan tidak memenuhi persyaratan, maka hal itu hanya akan menimbulkan mudharat lebih besar berupa perzinahan di kalangan masyarakat. Tidak cukup sampai disitu, dijelaskannya lebih jauh bahwa jika hal itu berlarut-larut, maka akan menimbulkan dampak yang lebih luas, yakni timbulnya suatu tatanan kehidupan umat dan perilaku pergaulan masyarakat yang tidak terpuji, serta rusaknya pola interaksi masyarakat khususnya dalam lembaga perkawinan itu sendiri.

Syukri Nur Alinti secara terang-terangan menginformasikan bahwa pasangan yang menikah di hadapan bapaknya dulu bukan hanya orang awam dalam persoalan hukum positif, oleh karena ada di antara mereka yang merupakan jaksa dan hakim, bahkan pegawai 
KUA. Menurut catatan bapaknya, Nur Alinti pernah menikahkan 4 (empat) orang kepala KUA, seorang di antaranya memalsukan identitas (karena tidak ingin diketahui dirinya sebagai kepala KUA), 3 (tiga) yang lainnya berterus terang tentang identitas itu. Bahkan Nur Alinti juga pernah menikahkan 2 (dua) orang hakim pengadilan negeri dan 2 (dua) orang jaksa. ${ }^{3}$

Penuturan di atas dibenarkan oleh Abd. Latif Littie, yang juga merupakan salah satu putra dari bapak Nur Alinti. Dalam wawancara dengannya, Abd Latif mengungkapkan bahwa:

"Sejak kecil, saya sudah menyaksikan bapak menikahkan orang yang datang kepadanya untuk sekedar minta tolong. Bahkan saya mengetahui bahwa mereka itu ada yang PNS, Hakim, Jaksa, serta ada juga tentara dan Polisi, termasuk mereka yang berpangkat tinggi. Tapi sebagian lainnya hanyalah masyarakat biasa yang umumnya datang dengan membawa pasangan perempuannya sudah dalam keadaan hamil...".

Penyedia layanan nikah tidak tercatat lainnya hampir semua menjadikan alasan ingin membantu yang bersangkutan agar terhindar dari zina sebagai justifikasi terhadap layanan yang dilakukan, sebagaimana terungkap kembali dalam penuturan Muh.Amin berikut:

"kami pada dasarnya hanya ingin membantu menyelamtkan mereka dari perzinahan, mka kalau Imam wilayah tidak ada dirumahnya, sayalah yang menikahkan pasangan yang bermohon tersebut. ${ }^{5}$

Dari ungkapan-ungkapan tersebut di atas, dapat dibangun hipotesis bahwa selain karena tersedianya ruang yang terbuka luas, motif orang melakukan nikah tidak tercatat adalah karena pasangan yang mengadu itu bermasalah secara hukum. Apa yang terungkap dari kasus-kasus yang melibatkan para PNS, dan atau bahkan pejabat, umumnya bermuara pada satu penyebab yakni kehendak untuk menikah kembali, sementara peraturan negara membatasinya. Begitu pula kasus yang disebutkan terakhir, sepertinya karena desakan keadaan, memaksa para pasangan tersebut memilih menyelesaikan masalahnya lewat cara-cara yang dianggapnya mudah.

\footnotetext{
${ }^{3}$ Wawancara dilakukan pada tanggal 3 Juni 2017

${ }^{4}$ Abd. Latif, Guru, Wawancara, 4 Oktober 2017.

${ }^{5}$ Muh. Amin (Penyedia Layanan Nikah Tidak Tercatat), Wawancara, 5 Mei 2017.
} 
Kecenderungan masyarakat memilih cara-cara penyelesaian masalah secara instan tersebut, pada sisi lain menujukkan kurangnya kesadaran mereka bahwa esensi perkawinan dalam Islam sungguh bukan sekedar pintu untuk melegalkan hubungan badan.

Oleh karena sejak awal perkawinan model tersebut dilakukan karena adanya masalah dan motif-motif lain yang tidak bisa sepenuhnya dipertanggungjawabkan, maka dalam kenyataannya kemudian, dari ribuan kasus pasangan nikah di bawah tangan yang pernah dinikahkan oleh Nur Alinti dan penyedia layanan nikah tidak tercatat setelahnya, tidak sedikit yang digugat oleh para pihak yang merasa dirugikan. Umumnya adalah para isteri yang dinikahi secara sah menurut hukum agama dan peraturan perundang-undangan. Kasus-kasus yang melibatkan PNS, umumnya dilaporkan istri pertama kepada instansi dan atasan dari suami pelaku nikah di bawah tangan tersebut.

Syukri Nur Alinti bahkan secara bersemangat menceritakan salah satu kasus menarka yang pernah ditangani bapaknya. Menurut penuturan Syukri, Nur Alinti pernah menikahkan seorang perempuan muallaf (tahun 1985), dengan wali bapaknya sendiri yang belum Islam. Peristiwa itu membuat bupati Kabupaten Gorontalo (Kasmat Lahay) ketika itu menggelar "rapat" (semi pengadilan) dalam rangka mengklarifikasi peristiwa tersebut. Ketika itu Bupati menghadirkan Ketua Pengadilan Agama Kabupaten (Drs. Hasiru) dan Ketua Pengadilan Agama Kota Gorontalo (Drs. Nasir Pomalingo), untuk 'menghakimi' perbuatan Alinti yang menikahkan seorang muallaf dengan wali non Islam. Ketika itu bapaknya (Nur Alinti) berargumen bahwa Rasulullah saja menikah dengan Khadijah dengan wali pamannya (Warakah Bin Naufal) yang ketika itu dia masih musyrik. Apakah pernikahan Nabi Saw. tidak sah? Pertanyaan bapaknya itu konon itu tidak dijawab oleh kedua Ketua PA tersebut.

Realitas nikah di bawah tangan di kota Gorontalo juga menunjukkan keunikan tersendiri. Meskipun bukan merupakan budaya, tetapi fenomena tersebut berjalan seiring dengan maraknya perbuatan "bahugel" di daerah ini, yang dalam batas tertentu bahkan terkesan dianggap lumrah. Karena itulah, tidak mengherankan jika tidak terlalu sulit untuk menemukan pasangan menyimpang dari pernikahan sah (selingkuh) di kota Gorontalo, baik yang telah melangsungkan pernikahan di bawah tangan dengan pasangan barunya, ataupun belum. Penuturan dan temuan peneliti di bawah ini menunjukkan fenemona tersebut. 
Adalah Ansar Olii ${ }^{6}$ menuturkan bahwa salah seorang pejabat di kantornya (nama dan jabatan dirahasiakan) telah memiliki 3 (tiga) orang istri, 2 (dua) di antaranya diduga dinikahi di bawah tangan di depan bapak Muhammad Nur Alinti. Perilaku pejabat yang telah menjadi "rahasia umum" di kalangan kantor BPN itu, nampaknya terbilang cukup rapi oleh karena sekalipun diduga istri ketiganya dinikahi secara siri/di bawah tangan, namun dia tetap dapat memiliki akta nikah.

Kasus berikut adalah seorang PNS bertugas di Kanwil Kemenag Propinsi Gorontalo. Kasus ini diungkapkan sendiri oleh yang bersangkutan dalam sebuah wawancara yang dilakukan dengannya. Berikut penuturannya :

"Pada mulanya saya hanya memiliki seorang istri, tapi karena tidak cocok kemudian cerai dengan istri saya yang pertama itu. Setelah cerai dengan istri pertama, pada tahun 2000 saya menikahi seorang wanita, namun tidak disetujui oleh orang tua saya. Tidak sampai setahun berselang, orang tua saya menginginkan saya menikah dengan wanita pilihannya, dan terjadilah pernikahan itu tanpa sepengetahuan istri kedua saya, dan pernikahan itu saya lakukan di Nur Alinti. Kemudian barubaru ini, karena saya memiliki utang sebanyak Rp. 13.000.000,(Tiga belas juta rupiah) pada seorang wanita, kemudian saya belum bisa melunasi utang itu. Wanita itu menawarkan bahwa utang saya akan lunas dengan syarat saya mau menikahinya, dan selanjutnya untuk melunasi utang itu, saya pun ke bapak Nur Alinti untuk menikahi wanita tersebut tanpa sepengetahun istri saya yang kedua dan ketiga". 7

Pada kasus yang ketiga ini adalah yang terjadi dengan seorang Pegawai senior di Pabrik Gula Rajawali yang bernama Malik Hasan. Berikut penuturannya:

"Saya awalnya sudah bahagia dengan seorang istri dan tiga orang anak. Alhamdulillah dengan penghasilan yang cukup yang saya peroleh dari perusahaan, saya dapat menghidupi anak dan istri secara layak. Namun setahun terakhir ini kemudian saya senang dengan wanita lain yang lebih muda. Hubungan saya dengan wanita tersebut membuat dia menjadi hamil, dan setelah usia kandungannya mencapai 6 bulan kami pun melangsungkan pernikahan di hadapan bapak Muhammad

\footnotetext{
${ }^{6}$ Ansar Olii, PNS, Wawancara, 15 Nopember 2017.

${ }^{7}$ Rahmat, PNS, Wawancara, 17 Juli 2017
} 
Nur Alinti. Hal itu saya lakukan tanpa sepengetahuan istri sah saya. Nanti setelah 6 bulan habis menikah dengan perempuan itu, istri pertama saya baru tahu, setelah mendapat informasi dari tetangganya yang mengetahui pernikahan kedua saya. Mengetahui saya telah menikah lagi, istri pertama saya itu menjadi sakit-sakitan, oleh karena dia diperhadapkan pada pada keinginan untuk cerai dengan beban hidup sendiri, ataukah berpoligami. Akhirnya istri saya itu belakangan sudah dapat menerima kehadiran istri kedua saya, namun dengan syarat penghasilan pokok tetap untuk istri pertama dan harta gono-gini tidak diberikan ke istri kedua", 8

Dari beberapa kasus di atas, muncul kesan bahwa umumnya motif pelakunya melakukan praktik nikah siri adalah untuk tujuan praktis pragmatis belaka. Tidak cukup bukti yang menunjukkan bahwa mereka melakukannya karena merasa dipersulit oleh aturan normatif, baik aturan agama maupun aturan perundang-undangan negara. Seolah-olah dengan nikah tidak tercatat itu, bagi mereka persoalannya telah selesai, tanpa menyadari bahwa sejak saat itulah persoalan besarnya bermula.

\section{Respon Masyarakat Muslim terhadap Praktik Nikah Tidak Tercatat}

Pro kontra respon masyarakat Muslim terhadap fenomena tersebut tentulah tidak dapat dihindari. Mulai dari pandangan yang ortodoks, moderat maupun yang liberal. Di luar komunitas yang memang terlibat langsung dalam praktek nikah siri, umumnya masyarakat Muslim Gorontalo menganggap pernikahan seperti itu sah-sah saja, sepanjang seluruh syarat dan rukunnya terpenuhi. Pemahaman seperti itu tentu saja dibangun berdasarkan pemahaman konvensional dan kurangnya kepedulian terhadap berbagai ekses yang ditimbulkan oleh nikah dengan cara seperti itu.

Pandangan yang moderat, umumnya melihat masalahnya dalam dua kutub yang berbeda. Bagi mereka, nikah tidak tercatat tetap sah, sepanjang syarat dan rukunnya terpenuhi, tetapi dikategorikan menyimpang karena tidak sesuai dengan peraturan perundangundangan. Dalam kaitan itu, Ison Salilama misalnya, mengapresiasi fenomena tersebut dengan ungkapan sebagai berikut:

"Bagi saya sebuah pernikahan itu di tentukan oleh substansinya bukan prosesnya. Oleh karena itu fenomena

\footnotetext{
${ }^{8}$ Malik Hasan, Karyawan PG. Rajawali. Wawancara, 22 Juni 2017.
} 
pernikahan seperti yang dipraktekkan masyarakat lewat Muhammad Nur Alinti, adalah fenomena yang wajar dan saya dapat memakluminya, sekalipun kemudian konteks tersebut dalam realitas kemasyarakatan menjadi fenomena yang pro dan kontra. Sebab bagi saya, tidak ada interpretasi yurisprudensi yang mutlak yang dapat menyimpulkan bahwa proses pernikahan seperti yang dipraktekkan tersebut tidak sah, utamanya jika kita mencermati dan menganut makna dari hukum Islam, bahwa sebuah pernikahan dapat dikatakan sah jika kedua mempelai ada, ada wali, saksi, dan mahar. Terkecuali jika kita mengacu pada Undang-undang perkawinan No. 1 tahun 1974...".9

Berbagai kalangan yang menunjukkan kepedulian dan memahami masalah hukum tidak sebatas wilayah hitam putih, justru berpendapat sebaliknya. Prof. Minhajuddin misalnya, secara bersemangat mengungkapkan betapa dangkalnya pemahaman keagamaan dan basis epistemologi orang yang memandang masalah nikah tidak tercatat hanya sebatas memenuhi syarat dan rukun dalam perspektif sederhana. Karena itu, secara tegas ia mengatakan bahwa nikah semacam itu tidak sah secara syar'i.

"Bagi saya kita harus berani mengatakan jika pernikahan semacam itu tidak sah. Sah tidaknya sebuah aktivitas ibadah, tidak boleh dipisahkan dari tujuan luhur dari ibadah itu sendiri. Esensi pernikahan Islam bukanlah sekedar lembaga untuk melegalkan hubungan badan, tetapi sebagai wadah kondusif bagi pembinaan generasi. Bagaimana mungkin tujuan luhur itu akan tercapai, jika sejak awal sudah dilakukan secara tidak bertanggung jawab. Wujud nyata dari keinginan bertanggung jawab, bukanlah dalam bentuk di luar yang direkomendasikan agama, melainkan dalam prosedur dan sistem absah yang memang ditunjukkan oleh agama. Daripada nikah sembunyisembunyi, mengapa tidak menikah secara terang-terangan, jika memang pelakunya memiliki niat yang baik untuk mencapai tujuan luhur dari pernikahan Islam. ${ }^{10}$

Karena itu, kata Minhajuddin, nikah semacam itu tidak diakui secara syar'i, begitu pula segala akibat yang ditimbulkan dari nikah semacam itu, dalam pandangan hukum Islam patut dipersoalkan. Oleh karena itu pernikahan semacam ini tidak boleh

\footnotetext{
${ }^{9}$ Ison Salilama, Mubaligh, Wawancara., 20 Agustus 2017.
}

${ }^{10}$ Minhajuddin, Akademisi. Wawancara, 24 Mei 2017. 
dilanggengkan, apalagi sampai menjadi solusi bagi problem pergaulan yang salah kaprah.

Dalam sudut pandang yang sama, salah seorang Hakim Pengadilan Agama Kab. Gorontalo, yang juga Ketua Pengadilan Agama, mengemukakan bahwa;

“...Dalam pandangan saya orang yang datang ke layanan nikah tidak tercatat, bukan untuk menikah, tapi sekedar untuk terbebas dari problem yang dia hadapi saat itu. Saya mengatakan demikian oleh karena pasangan yang datang ke sana umumnya bermasalah, kalau tidak bisa dikatakan seluruhnya adalah pasangan bermasalah. Saya mengatakan demikian oleh karena di antara mereka ada yang datang karena sudah hamil, ada juga karena persoalan terhambat oleh keharusan mendapatkan izin isteri pertama bagi PNS dan pejabat, bahkan ada yang tidak memiliki wali...". ${ }^{11}$

Dengan demikian, munculnya praktik nikah tidak tercatat dalam ruang yang agak terbuka, yang ditandai dengan hadirnya "layanan nikah swasta" di kota Gorontalo, ternyata kemudian melahirkan perspektif lain di kalangan masyarakat Gorontalo dalam memandang lembaga perkawinan. Lembaga perkawinan yang sejatinya harus dipandang sebagai lembaga yang akan melahirkan harmonisasi dan kebahagiaan dalam berumah tangga, kemudian beralih menjadi kurang harmoni dan kurang bahagia. Hal itu terutama disebabkan karena asas kenyamanan yang disandang dalam mengarungi bahtera rumah tangga tidak mungkin dapat dicapai melalui model perkawinan seperti yang dilakukan oleh oknum masyarakat yang menyelesaikan problem nikahnya di hadapan juru nikah swasta.

Dalam perspektif yang agak luas, sesungguhnya pernikahan yang dilakukan oleh seorang Muslim tanpa mengindahkan kaidah hukum yang ada, kurang lebih sama dengan melanggengkan atau bahkan melembagakan perzinahan di kalangan masyarakat. Ketika masyarakat membangun kesadarannya bahwa pernikahan yang penting sah, maka pintu bagi praktik pergaulan bebas sebenarnya telah dibuka secara sadar pula.

Kegelisahan semacam ini paling tidak terungkap dari wawancara dengan Hamka, seorang Hakim Pengadilan Agama di kota Gorontalo. Dituturkannya bahwa:

\footnotetext{
${ }^{11}$ Mukhtar, Ketua/Hakim Pengadilan Agama Gorontalo. Wawancara, 7 Agustus 2017.
} 
"Saya pernah menangani sebuah kasus gugat cerai yang diajukan oleh seorang wanita kepada suaminya dengan alasan tidak pernah mendapatkan nafkah batin dan materi lainnya, serta sering dipukul. Namun setelah di cross check dengan suami wanita ini, ternyata si wanita yang telah menikah terlebih dahulu dengan lelaki selingkuhannya di depan juru nikah swasta. Dan Apa yang dituduhkannya tadi hanyalah tameng untuk menjalin hubungan dengan suami yang menikahinya lewat nikah tidak tercatat. Ketika ditanyakan siapa yang jadi wali ketika dinikahkan, wanita tersebut menjawab; "ada tukang bentor yang mengantar saya ke tempat juru nikah swasta". 12

Dari sisi kesadaran hukum, tampak bahwa sebenarnya masih banyak masyarakat muslim yang peduli dengan praktik tersebut. Bahwa kasus yang sudah terjadi memang sudah demikian banyak dan memprihatinkan, akan tetapi, jauh lebih penting adalah meminimalkan terjadinya praktek serupa di masa yang akan datang. Kesadaran hukum seluruh masyarakat Muslim akan hakikat pernikahan Islam kiranya perlu disosialisaikan secara lebih mendalam, sehingga tidak tumbuh lagi pemahaman dan kesadaran sempit yang memandang pernikahan hanya untuk melegalkan hubungan badan, tidak dibangun untuk mencapai tujuan luhur perkawinan itu sendiri. Dalam konteks inilah, kajian berikut berupaya mengungkap perspektif Islam tentang hal tersebut dalam sudut pandang fiqh rekonstruktif.

\section{Rekonstruksi Terminologis dan Filosofis Pernikahan}

Dari sisi terminologi, sebenarnya fikih sudah memberi landasan kuat perlunya rekonstruktsi pemahaman tentang pernikahan. Bukabkah nuktah utama tujuan pernikahan adalah terbentuknya keluarga yang sakinah, mawaddah wa rahmah, keluarga yang tentram dan bahagia di bawah naungan ridha Allah SWT, sebagaimana disyariatkan dalam QS. Al-A'raf ayat 189.

Sesuai dengan sifat perbuatannya, pernikahan yang tidak tercatat, tampaknya akan sulit mendatangkan kebahagiaan dan ketentraman, karena sejak awal prosesnya sendiri telah memberi isyarat bahwa hal tersebut dilakukan karena adanya masalah serius. Ibnu Taimiyah bahkan secara tegas berpendapat bahwa pernikahan yang dilakukan dengan cara merahasiakannya, tanpa wali dan tanpa saksi-saksi (mushafahah) adalah pernikahan bathil. $^{13}$

\footnotetext{
${ }^{12}$ Hamka, Hakim PA Gorontalo, Wawancara, 8 Oktober 2017.

${ }^{13}$ Menurut Ibnu Taimiyah, nikah seperti itu termasuk jenis pernikahan pelacur atau dzawatil akhdan (perempuan yang mempunyai laki-laki piaraan)
} 
Pendapatnyatsersebut didasarkan pada hadis Nbi yang sangat masyhur bahwa "la nikaha illa bi waliyyin wa syahiday adlin"14 dengan pula hadis tentang tertib perwalian: "Perempuan yang mana saja kawin tanpa izin walinya maka pernikahannya bathil, maka pernikahannya bathil, maka pernikahannya bathil". ${ }^{15}$

Berdasarkan kedua hadis tersebut, Abu Hanifah, Syafi'i dan Ahmad berpendapat : "Tidak sah pernikahan melainkan dengan dua saksi”. Bahkan Imam Malik mewajibkan meramaikan pernikahan. ${ }^{16}$ Pendapat-pendapat di atas diperkuat pula dengan salah satu hadits Rasulullah Saw. yang ditulis dalam kitab Fiqh Asratul Muslimah karya Syaikh Hasan Ayyub, ${ }^{17}$ yang mengetengahkan bahwa pernikahan yang tidak dihadiri oleh suami, wali, dan dua orang saksi maka pernikahan tersebut termasuk zina.

Menurut jumhur ulama, sebuah pernikahan belum dianggap terlaksana, kecuali diumumkan secara terang-terangan (tidak sirri). Atau belum sah, kecuali para saksi yang hadir menyaksikan akad nikah yang dilangsungkan, meskipun penyiarannya dilakukan dengan sarana yang lain. Imam Malik, meskipun tidak mewajibkan pengumuman sebuah perkawinan secara luas, tetapi tetap perlu diketahui oleh orang-orang yang terdekat). ${ }^{18}$ Alasannya karena maksud dari pengumuman itu untuk menjaga keberlangsungan dari keturunan yang dihasilkan dari pernikahan tersebut. ${ }^{19}$

Berkaitan dengan pengumuman pernikahan, syariat Islam kemudian merekomendasikan diadakannya walimah al-'urs, yaitu perhelatan yang dilakukan setelah selesai akad nikah. Dasarnya adalah hadis Nabi: "Sesungguhnya Nabi Saw. Bertemu dengan Abdul Rahman bin 'Auf yang masih ada bekas kuning. Nabi Saw. berkata: "Ada apa ini?". Abdul Rahman berkata: "Saya baru mengawini

berdasarkan Q.S. Al-Baqarah: 221, An-Nisa: 25, dan An-Nur: 32. Lihat Ibnu Taimiyah. Ahkamuz-Zawaaj. Diterjemahkan oleh Rusnan Yahya dengan judul Hukum-hukum Perkawinan (Cet. I; Jakarta: Pustaka Al-Kautsar, 1997), h. 202.

${ }^{14}$ Diriwayatkan oleh Bukhari, dalam Shahihnya, oleh Abu Dawud, Tirmidzi, Ibnu Majah, Darimi, dan Ahmad bin Hambal masing-masing dalam sunannya. Sebagaimana dikutip Ibnu Taimiyah dalam ibid., h. 202-203.

${ }^{15}$ Diriwayatkan oleh Abu Dawud, At-Tirmidzi, Al-Darimi, dan Imam Ahmad masing-masing dalam kitab sunan dan musnadnya, dalam ibid., h. 203.

${ }^{16}$ Ibid.

${ }^{17}$ Syaikh Hasan Ayyub. Figh al-Asrah al-Muslimah. Diterjemahkan oleh M.Abdul Ghoffar,EM. dengan judul Fikih Keluarga (Cet.I; Jakarta: Pustaka AlKautsar, 2001), h. 58.

${ }^{18}$ Syaikh Kamil Muhammad Muhammad 'Uwaidah, "Al-Jami' Fii Fiqhi An-Nisa" diterjemahkan oleh M. Abdul Ghofar, EM dengan judul Fiqih Wanita (Edisi Lengkap) (Cet. I; Jakarta: Pustaka Al-Kautsar, 1998), h. 405.

${ }^{19}$ Ibid. 
seorang perempuan dengan mahar seberat biji kurma emas". Nabi bersabda: "Semoga Allah memberkatimu, adakanlah perhelatan walaupun hanya dengan memotong seekor kambing", ${ }^{20}$

Meskipun jumhur memahami perintahwalimah tersebuh hanya Sunnah, tetapi hikmahnya sangat jelas. Disunnahkannya mengadakan walimah adalah dalam rangka mengumumkan kepada khalayak bahwa akad nikah sudah terjadi sehingga semua pihak mengetahuinya dan tidak ada tuduhan serta implikasi hukum di kemudian hari. Sunatnya hukum mengadakan walimah mengandung pula arti sunnat mengundang khalayak ramai untuk menghadiri pesta itu.

Persoalannya kini, apakah perwalian dan persaksian yang dilakukan dalam praktik perkawinan dihadapan layanan nikah tidak tercatat cukup memenuhi syarat syar'i? Sudah pasti Sebuah pernikahan tidak sah, kecuali dengan dihadirkannya beberapa saksi, demikian menurut pendapat para ulama. Selain itu, hadirnya saksi berkaitan dengan hak dari kedua mempelai, utamanya mengenai keturunan atau anak, sehingga hal itu disyaratkan dalam akad nikah. Dengan maksud agar sang ayah tidak mengingkari anak yang nantinya dilahirkan dari hubungan pernikahan tersebut, sehingga terpelihara keutuhan dan keturunannya.

Dalam riwayat lain diceritakan bahwa pernah seorang lakilaki menikahi seorang wanita dengan disaksikan oleh dua orang lakilaki. Lalu orang tersebut meminta kedua saksi itu untuk merahasiakannya (sirri). Mengenai permintaan itu, ia (Imam Malik) menjawab: "Kedua mempelai harus dipisahkan dengan bercerai dan tidak diperbolehkan untuk menikah lagi. Sedang bagi si wanita boleh mengambil maharnya jika telah menerima dan bagi kedua saksi tersebut tidak mendapatkan sanksi apa-apa". ${ }^{21}$

Di luar ketentuan fikih, secara normatif hokum positif juga secara tegas konstruksinya memperkuat tujuan mulia perkawinan sebagai lembaga pembinaan/kaderisasi ummat.

Terdapat seperangkat aturan hukum Negara yang menguatkan tesis diatas. Referensi yang paling populer adalah Undang-undang No. 1 Tahun 1974 beserta peraturan pelaksanaannya. ${ }^{22}$ Khusus bagi umat

\footnotetext{
${ }^{20}$ Muhammad Fuad Abdul Baqi. “Al-Lu'lu Wal Marjan (Himpunan Hadits Sahih yang disepakati oleh Bukhari \& Muslim", diterjemahkan oleh H. Salim Bahreisy. (Surabaya; Pt. Bina Ilmu, t.th.), h. 486.

${ }^{21}$ Lihat Syaikh Kamil Muhammad Muhammad 'Uwaidah, op. cit., h. 406.

${ }^{22}$ Mohd. Idris Ramulyo, Hukum Perkawinan Islam-Suatu Analisis dari Undang-undang No. 1 Tahun 1974 dan Kompilasi Hukum Islam (Cet. IV; Jakarta: Bumi Aksara, 2002), h. 55.
} 
Islam, peraturan-peraturan pelaksanaannya juga djabarkan dalam Kompilasi Hukum Islam.

Dalam Peraturan Pemerintah Nomor 9 Tahun 1975 sebagai penjabaran dari Undang-undang Nomor 1 Tahun 1974, dikemukakan dalam pasal 2 bahwa : (1) Pencatatan Perkawinan dari mereka yang melangsungkan perkawinan menurut agama Islam, dilakukan oleh Pegawai Pencatat sebagaimana dimaksud dalam Undang-undang Nomor 32 Tahun 1945 tentang Pencatatan Nikah, Talak, dan Rujuk; (2) Pencatatan Perkawinan dari mereka yang melangsungkan perkawinan menurut agama dan keperayaannya itu selain agama Islam, dilakukan oleh Pegawai Pencatat Perkawinan pada kantor Catatan Sipil sebagaimana dimaksud perundang-undangan mengenai pencatatan perkawinan. $^{23}$

Dalam pasal 3 ayat 1 , disebutkan bahwa setiap orang yang akan melangsungkan perkawinan memberitahukan kehendaknya itu kepada Pegawai Pencatat di tempat perkawinan akan dilangsungkan. ${ }^{24}$

Sebagai penjabaran lebih lanjut dari aturan-aturan yang ada sebelumnya, maka dalam Kompilasi Hukum Islam (KHI) digariskan ketentuan teknis yang sifatnya lebih rinci, yakni:

1. Agar terjamin ketertiban perkawinan bagi masyarakat Islam setiap perkawinan harus dicatat.

2. Pencatatan perkawinan tersebut pada ayat (1), dilakukan oleh Pegawai Pencatat Nikah sebagaimana yang diatur dalam Undangundang No.22 Tahun 1946 jo Undang-undang No. 32 Tahun 1954.

3. Untuk memenuhi ketentuan dalam pasal 5, setiap perkawinan harus dilangsungkan di hadapan dan dibawah pengawasan Pegawai Pencatat Nikah.

4. Perkawinan yang dilakukan di luar pengawasan Pegawai Pencatat Nikah tidak mempunyai kekuatan Hukum.

5. Perkawinan hanya dapat dibuktikan dengan akta nikah yang dibuat oleh Pegawai Pencatat Nikah. ${ }^{25}$

Aturan tentang keharusan pencatatan perkawinan, sesungguhnya bukanlah hal baru bagi warga Negara Indonesia. Sebelum diberlakukannya UU No. 1 Tahun 1974, hal tersebut juga

\footnotetext{
${ }^{23}$ Lihat Departemen Agama RI-Direktorat Jenderal Bimbingan Masyarakat Islam \& Penyelenggaraan Haji. Peraturan Pemerintah Nomor 9 Tahun 1975 Tentang Pelaksanaan UU No. 1 Tahun 1974. (Jakarta: t.p., 2004), h. 68.

${ }^{24}$ Ibid., h. 69.

${ }^{25}$ Lihat Ibid., h. 70-71. Selengkapnya tentang hal itu dapat dilihat dalam Kompilasi Hukum Islam di Indonesia (Pasal 2 hingga pasal 7). Departemen Agama RI-Direktorat Jenderal Bimbingan Masyarakat Islam \& Penyelenggaraan Haji; Jakarta, 2004., h. 128-130.
} 
telah diatur dalam Undang-undang Hukum Perdata (Burgerlijk Wetboek). Dalam salah satu pasalnya disebutkan bahwa:

"Setiap orang yang hendak melakukan perkawinan harus terlebih dahulu memberitahukan kehendaknya itu kepada pegawai Catatan Sipil di tempat tinggal salah satu di antara keduanya dengan syarat-syarat yang cukup kepastian dan memperlihatkan kehendak kedua calon suami dan istri, izin orang tua atau wali pengawas atau keputusan Pengadilan Negeri bilamana diperlukan serta akta kelahiran calon suami istri", ${ }^{26}$

Selanjutnya dalam pasal lain dikemukakan pula tentang pencatatan perkawinan, yakni :

"Perkawinan tidak dapat dibuktikan dengan cara lain melainkan hanya dengan akta perkawinan yang diberikan oleh pejabat Catatan Sipil di mana perkawinan tersebut dilangsungkan, kecuali dalam hal-hal lain berdasarkan pertimbangan dari Hakim dengan bukti-bukti yang cukup mengenai ketidakadaan akta-akta perkawinan tersebut". 27

Meskipun dalam praktiknya kasus praktik nikah tidak tercatat juga melibatkan pasangan yang betul-betul baru pertama kali kawin, namun umumnya adalah pasangan (khususnya laki-laki) yang pernah dan atau telah memiliki isteri yang sah dan bermaksud untuk berpoligami. Aturan-aturan mengenai hal tersebut telah dijelaskan dalam pasal 3 dan pasal 4 UU No. 1 tahun 1974. Dalam pasal 3 ayat (1) misalnya dinyatakan bahwa: "Pada azasnya dalam suatu perkawinan seorang pria hanya boleh mempunyai seorang istri. Seorang istri hanya boleh mempunyai seorang suami”. Jadi pada dasarnya UU Perkawinan Indonesia menganut azas monogami. Dalam ayat (2) dinyatakan bahwa: "Pengadilan dapat memberi izin kepada seorang suami untuk beristri lebih dari seorang apabila dikehendaki oleh pihak-pihak bersangkutan". Hal ini berarti bahwa suami dapat diperbolehkan beristri lebih dari seorang apabila hal itu dikehendaki oleh suami dan istrinya.

Dalam pasal 4 ayat (1) dinyatakan: Dalam hal seorang suami akan beristri lebih dari seorang sebagaimana tersebut dalam pasal 3 ayat (2) Undang-undang ini, maka ia wajib mengajukan permohonan kepada Pengadilan di daerah tempat tinggalnya. Selanjutnya dalam pasal 4 ayat (2) dinyatakan bahwa: Pengadilan dimaksud dalam ayat

\footnotetext{
${ }^{26}$ Mohd. Idris Ramulyo, op.cit., h. 61.

${ }^{27}$ Ibid., h. 62.
} 
(1) pasal ini hanya memberikan izin kepada seorang suami yang akan beristri lebih dari seorang (berpoligami) apabila:

1. Istri tidak dapat menjalankan kewajibannya sebagai istri.

2. Istri mendapat cacat badan atau penyakit yang tidak dapat disembuhkan.

3. Istri tidak dapat melahirkan keturunan. ${ }^{28}$

Dari berbagai ungkapan pasal-pasal dari undang-undang perkawinan di atas, nampak bahwa dalam hukum positif (utamanya undang-undang perkawinan Indonesia UU No. I Tahun 1974), ruang untuk melakukan poligami memang agak sempit.

Dalam analisa Muhammad Abduh Malik, ${ }^{29}$ selama ini umumnya latar belakang terjadinya nikah tidak tercatat adalah lebih disebabkan oleh pihak pengantin pria dan wanita tersebut ingin menghindar dari UU Perkawinan No. 1 Tahun 1974. Berkaitan dengan hal tersebut, ia menawarkan perlunya sanksi pidana bagi siapa saja yang melanggar seperti yang dimaksudkan oleh Peraturan Pemerintah RI Nomor 9 Tahun 1975 tentang pelaksanaan UU RI No. 1 Tahun 1974 tentang perkawinan. Selama ini memang telah ada aturan tentang hal itu, tetapi tampaknya jenis sanksinya kurang realistis, sehingganya perlu dirumuskan ulang, sehingga efek jera dari sebuah sanksi hukum, dapat tercapai.

Sekedar sebagai pembanding, dalam studi yang di lakukan oleh A.Wasit Aulawi, ${ }^{30}$ dikemukakan bahwa terjadinya praktik nikah tidak tercatat disebabkan oleh beberapa faktor, diantaranya: (1) faktor pengetahuan masyarakat yang kurang, (2) faktor fiqh yang tidak mengatur batas umur nikah, dan (3) faktor kekhawatiran orang tua yang berlebihan terhadap jodoh anaknya. ${ }^{31}$ Dalam perspektif yang lain Wildan Suyuti Mustofa, ${ }^{32}$ mengemukakan bahwa paling tidak ada dua penyebab masyarakat melakukan nikah tidak tercatat, pertama : Adanya faktor-faktor di luar kemampuan si pelamar, yang meliputi: (a) Menjaga hubungan antara laki-laki dan perempuan agar terhindar dari hal-hal yang terlarang menurut agama, karena masih sama-sama

\footnotetext{
${ }^{28}$ Lihat Ibid. Selengkapnya hal tersebut dapat dibaca dalam Undang-undang No. 1 Tahun 1974 tentang Perkawinan dan Peraturan Pemerintah RI No. 9 Tahun 1975 tentang pelaksanaan UU No. 1 Tahun 1974. Departemen Agama RI. Direktorat Jenderal Bimbingan Masyarakat Islam dan Penyelenggaraan Haji; Jakarta, 2004.

${ }^{29}$ H. Muhammad Abduh Malik, Nikah-Talak Di "Bawah Tangan".op.cit., h. 121 .

${ }^{30}$ Lihat H.A. Wasit Aulawi, Pernikahan Harus Melibatkan Masyarakat. Jurnal Mimbar Hukum. op.cit., h. 21.

${ }^{31}$ Ibid., h. 22.

${ }^{32}$ H. Wildan Suyuti Mustofa, Nikah Sirri (Antara Kenyataan dan Kepastian Hukum). Jurnal Mimbar Hukum. Ibid., h.36.
} 
kuliah atau sambil menunggu selesai kuliah, (b) Tidak adanya izin wali nikah (orang tua), (c) Sulitnya memperoleh izin dari istri dalam hal suami akan menikah lebih dari seorang, dan (d) Adanya kekhawatiran kehilangan hak pensiun janda. Yang kedua adalah adanya pendapat bahwa pencatatan nikah tidak merupakan perintah agama, karena tidak dilakukan di zaman Nabi.

Apapun perspektif orang terhadap masalah ini, pada akhirnya harus ditegaskan bahwa praktik nikah tidak tercatat merupakan ekpresi nyata terjadinya simplikasisasi terhadap perkawinan. Seolaholeh esensi perkawinan hanyalah semata melegalkan hubungan badan, sehingga syarat-syarat lainnya cenderung disepelekan karena dianggap bukan bagian dari perintah agama.

Selain persoalan filosofis, penelusuran di lapangan menunjukkan bahwa munculnya simplikasisasi terhadap esensi perkawinan berawal dari terminologi yang disosialisasi dan dipahami oleh masyarakat tentang arti nikah. Selama ini terminologi nikah yang dipopulerkan adalah suatu akad antara seorang pria dengan seorang wanita atas dasar kerelaan dan kesukaan kedua belah pihak, yang dilakukan oleh pihak lain (wali) menurut sifat dan syarat yang telah ditetapkan oleh syara' untuk menghalalkan pencampuran antara keduanya, sehingga satu sama lain saling membutuhkan menjadi sekutu sebagai teman hidup dalam rumah tangga". 33 Sementara dalam Kamus Besar Bahasa Indonesia dikemukakan pengertian "nikah" sebagai "perjanjian antara laki-laki dan perempuan untuk bersuami istri (dengan resmi)". ${ }^{34}$ Dalam term yang lain pernikahan yang bermakna al-zawaj berarti iqtiran (bergandengan), dan izdiwaj (berpasangan). Pakar Bahasa mengatakan : Kata At-Tazawuj, AlMuzawajah, dan Al-Izdiwaj artinya sama yakni berpasangan. ${ }^{35}$

Menurut pandangan fuqaha Hanafiah, Az-Zawaj adalah akad nikah yang dilangsungkan untuk memberi hak kepada laki-laki melakukan hubungan sex dengan perempuan yang diakad (nikahi)".36 Dengan Zawaj seorang laki-laki dipersilahkan melakukan hubungan sex dengan perempuan yang telah dinikahinya.

Berbeda dengan terminologi yang dimunculkan dalam kitabkitab fikih, dalam UU tampak lebih substansial dan konprehensif.

\footnotetext{
${ }^{33}$ Slamet Abidin \& H.Aminuddin. Fiqih Munakahat 1(Cet. I; Bandung: Pustaka Setia, 1999), h. 11-12.

${ }^{34}$ Departemen Pendidikan \& Kebudayaan. Kamus Besar Bahasa Indonesia (Cet. II; Jakarta: Balai Pustaka, 1989), h. 614.

${ }^{35}$ Muhammad Raf'at Utsman. "Fiqhun Nisa Fil Khitbah waz Zawaj" Diterjemahkan oleh Muzaidi Hasbullah, Lc dengan judul Fiqhi Wanita Muslimah Seputar Hukum Khitbah dan Nikah (Cet. I; Solo: Pustaka Arafah, 2002), h. 16.

${ }^{36}$ Ibid., h. 17.
} 
Dalam UU No. 1/1974 tentang perkawinan, didefinisikan bahwa "perkawinan ialah ikatan lahir batin antara seorang pria dengan seorang wanita sebagai suami isteri dengan tujuan membentuk keluarga (rumah tangga) yang bahagia dan kekal berdasarkan Ketuhanan Yang Maha Esa.”

Hakikat perkawinan yang digambarkan dalam UU No. 1/1974 itu tampak sejalan dengan hakikat perkawinan Islam, karena keduanya tidak hanya melihat dari segi ikatan kontrak lahirnya saja, tapi sekaligus ikatan pertautan kebatinan antara suami isteri yang ditujukan untuk membina keluarga yang kekal dan bahagia sesuai dengan kehendak Tuhan yang Maha Esa. Kedua bentuk hukum tersebut berbeda dengan hukum Barat-Amerika yang memandang perkawinan hanya merupakan bentuk persetujuan dan kontrak kesepakatan, juga berbeda dengan perkawinan dalam BW yang hanya menganggapnya sebagai persetujuan perikatan. ${ }^{37}$

Asaf A.A. Fyzee merinci tujuan perkawinan dalam tiga aspek, yaitu: (1) aspek agama, meliputi pengertian (a) perkawinan merupakan pertalian yang teguh antara suami dan isteri serta keturunan, (b) merupakan salah satu sunnah Nabi, (c) perkawinan mendatangkan rezeki, (d) isteri merupakan simpanan yang paling baik; (2) aspek sosial, meliputi (a) memberikan perlindungan kepada kaum wanita, baik nafkah maupun gangguan fisik lainnya, (b) mendatangkan sakinah (ketenangan) bagi suami, (c) sebagai solusi terciptanyan stabilitas dalam masyarakat; (3) aspek hukum, dalam pengertian perkawinan menimbulkan hak dan kewajiban. ${ }^{38}$

Dengan demikian, sebagai theoritical frame work, dapat ditegaskan bahwasanya segala bentuk perkawinan yang tidak dan atau kemungkinan tidak akan memenuhi tujuan-tujuan luhur seperti yang disebutkan diatas, adalah penyederhanaan pandangan terhadap kesucian dan keluhuran nilai-nilai perkawinan itu sendiri.

\section{Kesimpulan}

Perkawinan Islam sejatinya menjadi ruang yang representatif bagi pembentukan keluarga yang sakinah, mawaddah wa rahmat. Kategorisasi keluarga yang ideal tersebut salah satunya dapat terwujud jika prosesi perkawinannya berlangsung secara tertib, baik dari sisi substansi maupun adminsitrasi. Sayangnya praktik nikah tidak tercatat yang marak terjadi di Gorontalo secara terang-terangan mengabaikan

\footnotetext{
${ }^{37}$ Lihat A.P. Grabtru, L.L.B. You and The Law (New York: Halt Rinihart and Wiston Inc, t. th), h. 139.

${ }^{38}$ Sebagaimana dikutip Ramlan Yusuf Rangkuti, dalam Chuzaimah T.Yanggo, Problematika Hukum Islam Kontemporer (Jakarta: Pustaka Firdaus, 2002), h. 57-62.
} 
aspek adminstrasi perkawinan, padahal sejumlah dalil agama secara jelas merekomendasikan pentingnya merapikan aspek tersebut.

Lebih dari itu, layanan nikah tidak tercatat juga berkorelasi langsung dengan kesadaran masyarakat Muslim tentang epistemologi perkawinan. Karena seringnya publikasi dan sosialisasi tentang terminologi nikah yang cenderung simplistik, maka tertanam di alam bawah sadar seolah-olah pernikahan Islam hanya sekedar melegalkan hubungan badan agar terhindar dari zina. Rekonstruksi epistemologis bukan hanya mengandaikan perubahan pada epistemologi dasar, tetapi juga pendekatan dan metode serta publikasi pemikiran yang lebih egaliter, berkelanjutan dan memperhatikan aspek-aspek mendasar dari esensi syariah sebagaimana termaktub dalam maqashid al-syariah.

\section{Daftar Pustaka}

Aulawi, Wasit. Pernikahan Harus Melibatkan Masyarakat. Jurnal Mimbar Hukum.

Ayyub, Hasan. Fiqh al-Asrah al-Muslimah. Diterjemahkan oleh M.Abdul Ghoffar,EM. dengan judul Fikih Keluarga, Cet.I; Jakarta: Pustaka Al-Kautsar, 2001.

Baqi, Muhammad Fuad Abdul. "Al-Lu'lu Wal Marjan, Himpunan Hadits Sahih yang disepakati oleh Bukhari \& Muslim", diterjemahkan oleh H. Salim Bahreisy, Surabaya; Pt. Bina Ilmu, t.th.

Departemen Agama RI-Direktorat Jenderal Bimbingan Masyarakat Islam \& Penyelenggaraan Haji. Peraturan Pemerintah Nomor 9 Tahun 1975 Tentang Pelaksanaan UU No. 1 Tahun 1974. (Jakarta: t.p., 2004.

Departemen Agama RI-Direktorat Jenderal Bimbingan Masyarakat Islam \& Penyelenggaraan Haji; Jakarta, 2004

Departemen Pendidikan \& Kebudayaan. Kamus Besar Bahasa Indonesia, Cet. II; Jakarta: Balai Pustaka, 1989.

Grabtru, A.P. L.L.B. You and The Law, New York: Halt Rinihart and Wiston Inc, t. th.

Muhammad, Kamil Muhammad. 'Uwaidah, "Al-Jami' Fii Fiqhi AnNisa"" diterjemahkan oleh M. Abdul Ghofar, EM dengan judul Fiqih Wanita, Edisi Lengkap) (Cet. I; Jakarta: Pustaka AlKautsar, 1998. 
Mustofa, Wildan Suyuti. Nikah Sirri (Antara Kenyataan dan Kepastian Hukum, Jurnal Mimbar Hukum. Ibid., h.36.

Ramulyo, Mohd. Idris. Hukum Perkawinan Islam-Suatu Analisis dari Undang-undang No. 1 Tahun 1974 dan Kompilasi Hukum Islam, Cet. IV; Jakarta: Bumi Aksara, 2002.

Rangkuti, Ramlan Yusuf. dalam Chuzaimah T.Yanggo, Problematika Hukum Islam Kontemporer, Jakarta: Pustaka Firdaus, 2002.

Slamet, Abidin \& H.Aminuddin. Fiqih Munakahat, Cet. I; Bandung: Pustaka Setia, 1999.

Syatibi, Abu Ishaq. al-Muwafaqat fiy Ushul al-Syari'ah, Jilid III, Beirut: Dar al-Ma'rifah li al-Thiba'ah wa al_Nasyr, 1975.

Taimiyah, Ibn. Ahkamuz-Zawaaj. Diterjemahkan oleh Rusnan Yahya dengan judul Hukum-hukum Perkawinan, Cet. I; Jakarta: Pustaka Al-Kautsar, 1997.

Utsman, Muhammad Raf'at. "Fiqhun Nisa Fil Khitbah waz Zawaj” Diterjemahkan oleh Muzaidi Hasbullah, Lc dengan judul Fiqhi Wanita Muslimah Seputar Hukum Khitbah dan Nikah, Cet. I; Solo: Pustaka Arafah, 2002. 